\title{
REGIONAL EFFECTS OF THE GLOBAL CLIMATE CHANGE; A CASE STUDY: THE SOCHI NATIONAL PARK AREA (RUSSIA)
}

\author{
Elena A. Rybak ${ }^{1,2}$, Oleg O. Rybak ${ }^{1}$ \\ ${ }^{1}$ Sochi Scientific Research Centre of the Russian academy of sciences, Russia \\ ${ }^{2}$ Sochi National Park, Russia \\ e-mail: elena.rybak@gmail.com
}

Received: 01.09.2017

\begin{abstract}
The Sochi National Park (SNP) occupies a considerable territory within the Greater Sochi municipality. It is located in several altitudinal zones. Therefore, climatic conditions within its territory are rather diverse. The average climatic conditions of SNP are rather well studied, but the global and regional climate change together with long tendencies in natural climate variability, require regular updating of corresponding changes on the SNP territory. This is important, first of all, for tracking changes and establishing reasons in local biodiversity changes. In the paper, we consider recent variations of the key climatic characteristics (air surface temperature and precipitation amount) in three elevation zones of the SNP. Analyses of mean annual and mean seasonal values reveal that besides common features, climatic tendencies are influenced by local conditions. Positive trends were established in temperature time series and negative in precipitation ones.
\end{abstract}

Key words: air temperature, climate change, global climate, precipitation amount, regional climate

\section{Introduction}

At present, the majority of the scientific community is convinced in the reality and in the significance of the contemporary climate change caused by human activities. Following definitions adopted by the Intergovernmental Panel on Climate Change (IPCC) in the Fourth Assessment Report (IPCC, 2007), climate change is determined as «a change in the state of the climate that can be identified (e.g. using statistical tests) by changes in the mean and/or the variability of its properties, and that persists for an extended period, typically decades or longer.» It refers to any change in climate over time, whether due to natural variability or as a result of human activity. The above mentioned point of view has not been revised in the next report, the Fifth Assessment Report, published six years later. Climate variations in historical time can be caused either by natural processes or may have an anthropogenic origin. Note that the IPCC definition is somewhat different from other existing wide-spread ones, for instance, from that in the United Nations Framework Convention on Climate Change (UNFCCC), «...where climate change refers to a change of climate that is attributed directly or indirectly to human activity that alters the composition of the global atmosphere and that is in addition to natural climate variability observed over comparable time periods.» (IPCC, 2007). In reality, it is perhaps impossible or at least difficult to clearly separate natural and anthropogenic sources of climate change.

Both regional and global climate changes for a certain time period are defined as a difference (anomaly) between the current value of a climatic variable and the "climatic norm» (i.e. an average for a conventional period of time; the commonly accepted period is 1961-1990). Climate variations have always had a strong societal impact. Numerous indirect evidences of the pre-instrumental era (including various historical documents) point to relatively warm and cold, humid and dry periods in the past. In any case, the society (to be more precise, various human societies) has always been forced to adjust to climatic variations pursuing a sole purpose - surviving of the community. In other words, during any of such comparatively «extreme» time periods, the challenge of environmental change compelled the society to elaborate a strategy of adaptation to the changing outer world. A similar situation exists nowadays. Our civilization faces numerous dangers and challenges of climate change. Although their analysis is beyond the scope of the current paper, we would like to outline one notable issue. In contrast to the past, the contemporary society is capable to assess possible consequences of climate change several decades in advance, and, 
thus, has at least a chance to elaborate strategies of mitigation of its consequences.

Ecological systems and the social-economical structure of modern society are rather sensitive not only to climate change itself, but also to the rate of change. Besides, climate change causes additional stress on the systems, which already experience negative consequences of a growing natural resources demand and irrational or erroneous management or/and pollution.

The growing concentration of greenhouse gases in the atmosphere amplifies natural trends in climate change. This is probably the main cause why older climatic norms become outdated. One cannot rely on them making decisions on development of energy production, transportation, agriculture etc. Because of that, the World Meteorological Organisation adopted a new technical regulation about innovation of climatic norms. This regulation approves the simultaneous existence of two norms - a new operational (allowing utilitarian usage) and the old, historical (allowing scientific and societal understanding of climate change rates). For example, norms for an operational evaluation of climate change will be recalculated every 10 years. A new basic climate period will be associated with the series of 1981-2010 and later, in the next decade (2020-ies) - with the period 1991-2020. At the same time, to sustain a longterm climate change evaluation, the old historical series of 1961-1990 will be used (WMO, 2011).

The multiyear variability of air temperature on the regional scale reflects large-scale processes in the climate system of the Earth. In the particular region under consideration in this paper, a decisive factor is the atmospheric circulation over the Euroatlantic region. With a decrease of the averaging scale, dynamics of seasonal averages of air temperature will strongly depend on regional peculiarities - insolation, local atmospheric circulation, relief, water objects, snow cover. Alongside with a commonly recognised gradual increase of the global air temperature, many researches find similar trends on the regional level, including in various parts of Russia. For instance, in the Southern Federal District positive temperature anomalies of the climatic norm during the decade 1998-2007 prevailed over the negative ones (54\% vs $19 \%)$. A maximum warming was observed in winter months (Khovanova, 2009). Similar results were obtained by Ashabokov et al. (2017) for the time period 1961-2011 for the Eu- ropean territory of Russia. In contrast to the work of Khovanova (2009), Ashabokov et al. (2017) indicated that maxima of the rates of temperature growth were observed in the summer time.

The role of climate is unequivocally appreciated as a «. new factor of human «enforcement» on nature» (IPCC, 2007). The latter obviously means that weather and climate observations and analysis have not only academic or pure practical values (weather forecasts etc.) but shall be applied for evaluation of climate dependent environmental changes. In line with it, the main goals of the World Climate Research Programme are climate predictions, forehanded identification of consequences of human impact and other external factors influencing the environment. The growing interest to protected areas (PAs), including e.g. national parks, can be explained mostly by the development of ecological tourism and by the role, which these territories play in providing sustainable development of the environment. In Russia, a formidable net of PAs is represented by 103 reserves, 48 national parks, 64 federal wildlife sanctuaries and nearly by 13 thousand of their regional analogues. In total, the territory of PAs in Russia exceeds $11 \%$ of the country's area according to WWF (https://new.wwf.ru). The Sochi National Park ${ }^{1}$ (SNP) is a typical PA, where climate (more correctly, several diverse climates, taking into consideration the area of the park and the range of altitudes of its territory) is the major factor determining its specific natural characteristics. An effective operating of the SNP requires understanding the environmental changes in the region including variations of the regional climate. No doubt, climate change affects biodiversity. Particularly, we can point to changes in the traditional area of species' habitat, shifts in the sequence of biological events, violation of synchronous interactions in ecosystems (e.g., interaction between plants and insects-pollinators), the impact on demographic characteristic of species such as fertility and survival, decrease of population, extinction of species, spread of diseases.

Trends in climatic time series in the Black Sea region were analysed earlier (e.g. Rybak et al., 2013; Rybak \& Rybak, 2015; Evstigneev et al., 2016; Ashabokov et al., 2017). These studies were based on the meteorological data from weather stations located on the territory of the

\footnotetext{
$\overline{1}$ Sochi National Park $\left(1937.37 \mathrm{~km}^{2}\right)$ was founded in 1983: http://www.zapoved.net/
} 
SNP. In previous years, up to 35 weather stations were operating on the territory of Greater Sochi (Rybak et al., 1994). At present, only 7 have remained (Sochi, Krasnaya Polyana, Adler, Lazarevskaya, Kordon Laura and two automatic weather stations at Gornaya Karoussel mountain resort). In a rather comprehensive review, Rybak (2006) described climatic conditions of the SNP including an overview of mechanisms driving climatic variability within the territory of the SNP. In this study, we focus on the period 2000-2016 to establish very recent tendencies in the changing regional climate. Microclimates of the SNP territory are formed mostly by elevation. That is why we consider three main elevation zones: the coastal zone (0-200 $\mathrm{m}$ above sea level, a.s.1.), the piedmont zone (200-600 m a.s.1.) and the middle altitude zone (above $600 \mathrm{~m}$ a.s.1.). The territory above $2500 \mathrm{~m}$ a.s.1. (formally referred as the high-mountain zone) is small compared to the territory of the other zones, and, more important, it is in practice unstudied from the climatic point of view. Therefore, it is not possible to analyse changes in climatic conditions here. Temperature and precipitation regimes of the three elevation zones are well described by time series from the weather stations Sochi (57 m a.s.1.), Krasnaya Polyana (567 m a.s.1.) and Dzhuga (2000 m a.s.1.).

\section{Regime of air temperature}

The decade 2000-2010 was the warmest on the Earth during the whole period of instrumental observations (Mokhov \& Semenov, 2016), when the global surface air temperature exceeded the climatic norm by $0.5^{\circ} \mathrm{C}$. As clearly indicated in Fig. 1-3, in our region, 2010 was the warmest year during the analysed period.

The anomalously hot summer of 2010 in our region and, in general, in the European territory of Russia is explained by a blocking effect in the troposphere of middle latitudes. Extremely warm temperatures were enforced by advection of warm and dry air from southwestern regions with reduced soil water storage (Volodin, 2011). For comparison, to the north of the main Caucasus chain (in Elbrus' surroundings) the warmest period was in 19511960 (Korchagina, 2017). Further analysis reveals that in all elevation zones stable warming tendency exists both in warm and in cold seasons and in annual averaging (Table). Warm trends are stronger in winter (middle altitude zone) and in summer (coastal and piedmont zones) compared to annual averages. The above estimates have a similar order of magnitude as estimates for air temperature trends over land areas of the Northern Hemisphere, $0.328^{\circ} \mathrm{C} / 10$ years (Gruza \& Rankova, 2012), for the territory of Russia, $0.43^{\circ} \mathrm{C} / 10$ years (Second Roshydromet assessment report, 2014). Somewhat smaller trends were revealed for the Black Sea area (period $1976-2012$ ), $0.06^{\circ} \mathrm{C} / 10$ years, and for the piedmont area of the North Caucasus (Kislovodsk) and Caspian coast $\left(0.07\right.$ and $0.08^{\circ} \mathrm{C} / 10$ years respectively) (Ashabokov et al., 2017).

A remarkably small trend in winter was observed in the coastal zone. In general, temperatures grow faster in summer than in winter (except middle altitude zone). A maximum rate of temperature increase was marked in summer (piedmont zone). The increase of annual temperatures goes alongside with similar changes in the southern part of the European Territory of Russia (Ashabokov et al., 2017). In general, the rate of air temperature change in our region well agrees with the estimates made earlier by Rybak \& Rybak (2015) for the preceding period.

The recent years are marked by several extremely cold winters in the European Territory of Russia and in the North Caucasus region. This is explained by the advection of the Arctic air to middle latitudes, which causes an abrupt and rapid temperature decrease (cold waves). The Caucasus mountains prevent a deep penetration of the cold air towards the Black Sea Coast. In addition, a temperature decrease is mitigated by strong thermal inertia of the Black Sea. That is why (also taking into account that cold intrusions are not prolonged phenomena) winter temperatures in the last years follow generally a positive tendency.

\section{Regime of precipitation}

In our study, we consider precipitation irrespective of its type (i.e. solid, liquid or mixed). On the global scale, in the $20^{\text {th }}$ century the precipitation amount was growing on the Northern Hemisphere in most parts of the continents at high and middle latitudes and, simultaneously, decreased in the greater part of the subtropics (Kondratyev \& Demirchyan, 2001). Opposite to the latter tendency, linear trends, though very small, are negative (Fig. 4). In the piedmont and in the middle altitude zones the precipitation trend is better approximated by a $3^{\text {rd }}$ order polynomial function. Notably that the amount of precipitation exceeded the climatic norm in most years. 

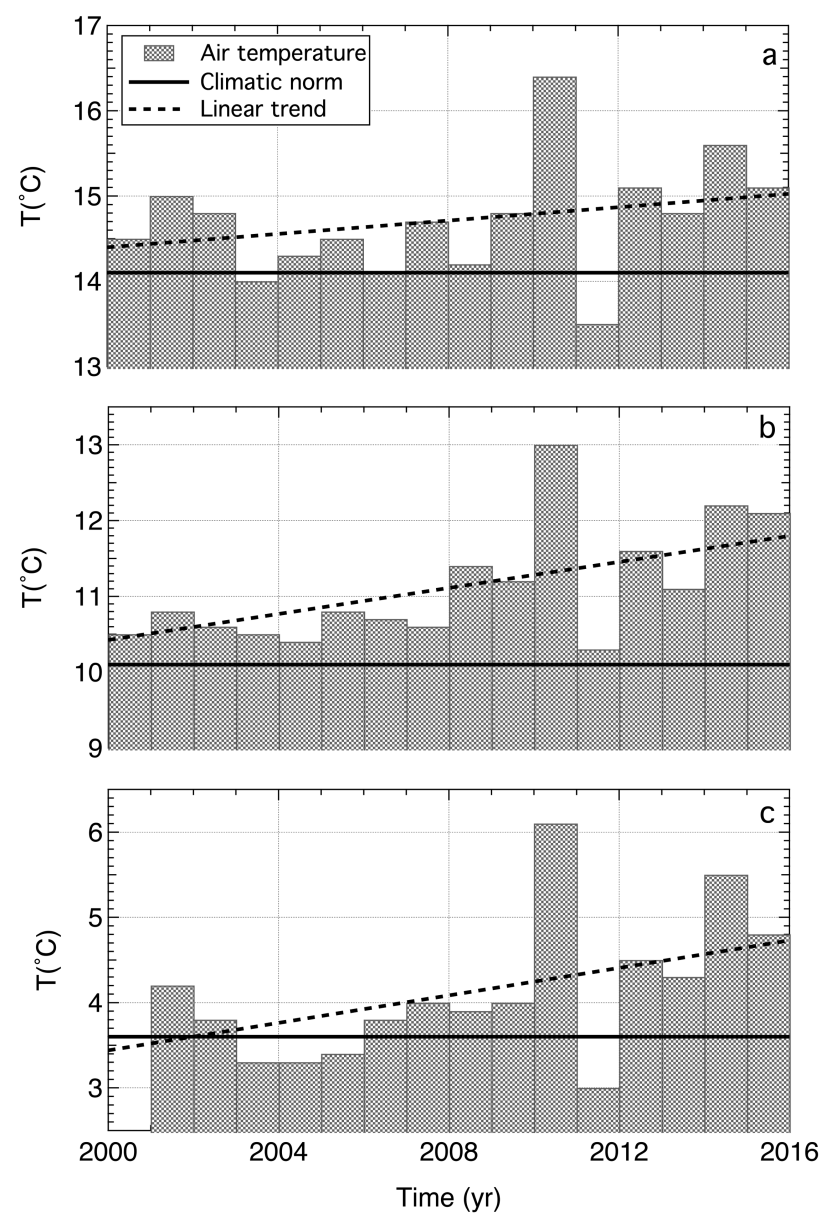

Fig. 1. Average annual air temperatures, their climatic norms and linear trends for weather stations Sochi (a), Krasnaya Polyana (b) and Dzhuga (c).

The identification of trends in precipitation time series is more complicated compared to the case of air temperature. This fact is explained by a high interannual variability of precipitation. Besides, the spatial structure of the precipitation field is determined by local factors, especially by relief. In certain cases, the interannual variability of precipitation may have resembled the quasi-cycle regime or long-term trends.

That is why we cannot support or reject the hypothesis on the direct dependence of a local precipitation field on global warming. It is more reasonable to suppose that a change in the precipitation regime of a relatively small territory depends on global climatic changes via variations in the atmospheric circulation. The climate of our region is influenced by the North Atlantic Oscillation, NAO (Rybak \& Rybak, 2015; Evstigneev, 2016), which has presumably a quasi-cyclic variability (Rybak \& Rybak, 2009). Thus, the interannual precipitation variability in the Black Sea region is formed by
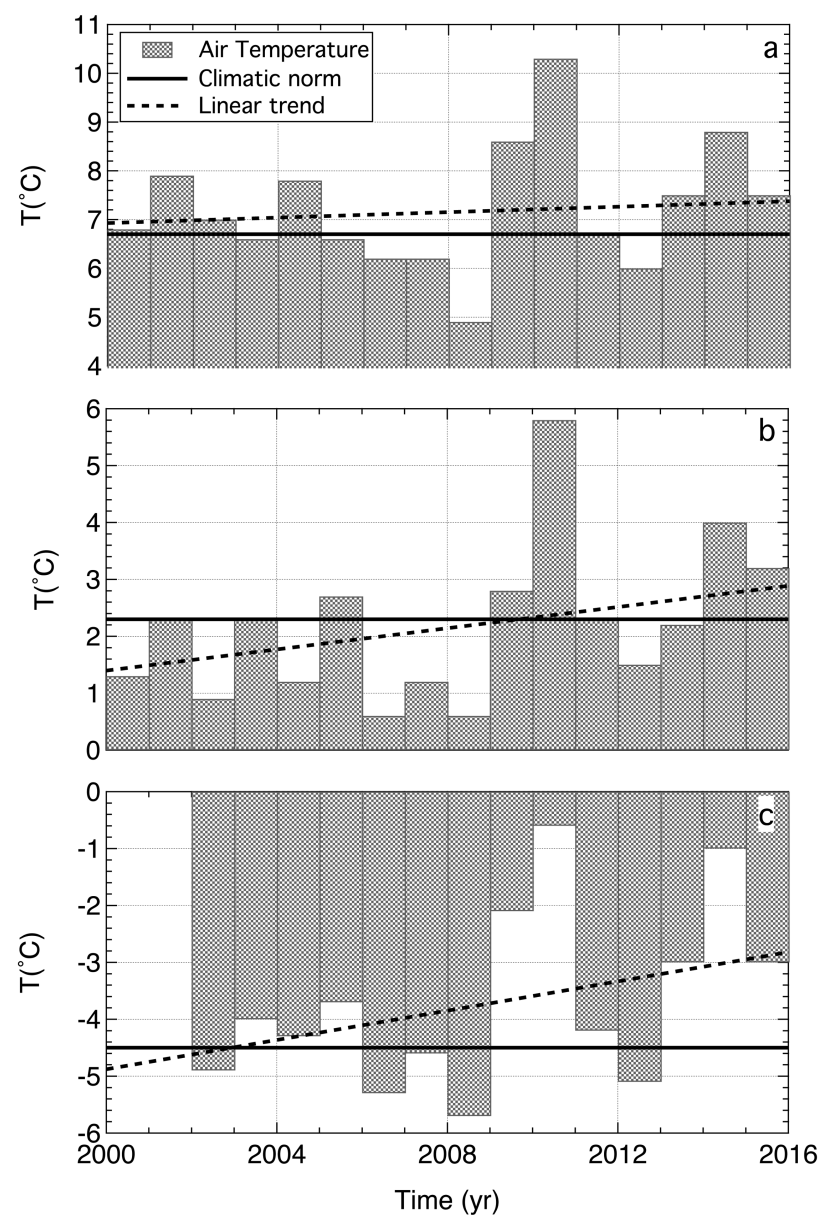

Fig. 2. Winter (DJF) average air temperatures, their climatic norms and linear trends for weather stations Sochi (a), Krasnaya Polyana (b) and Dzhuga (c).

variations of the atmospheric circulation over Europe superimposed by small-scale factors and is dependent to a much lesser degree on global climate change.

The seasonal regime of precipitation is analysed by comparing two periods - warm (April - September) and cold (October - March) (Fig. 5). Interestingly, the Black Sea Coast is the only region in Russia with prevailing winter precipitation (Second Roshydromet assessment report, 2014), although Ashabokov et al. (2017) expand the area with prevailing winter precipitation to the Caspian coast and to the steppe zone. In our case, an exception is the middle altitude zone (Fig. 5c) where the average precipitation rate in a warm period is higher than in a cold one.

Table. Rate of air temperature change, ${ }^{\circ} \mathrm{C} / 10$ years

\begin{tabular}{|c|c|c|c|}
\hline Elevational zone & Year & Summer & Winter \\
\hline Coastal & 0.4 & 0.6 & 0.3 \\
\hline Piedmont & 0.6 & 1.4 & 0.1 \\
\hline Middle altitude & 0.3 & 0.2 & 0.5 \\
\hline
\end{tabular}



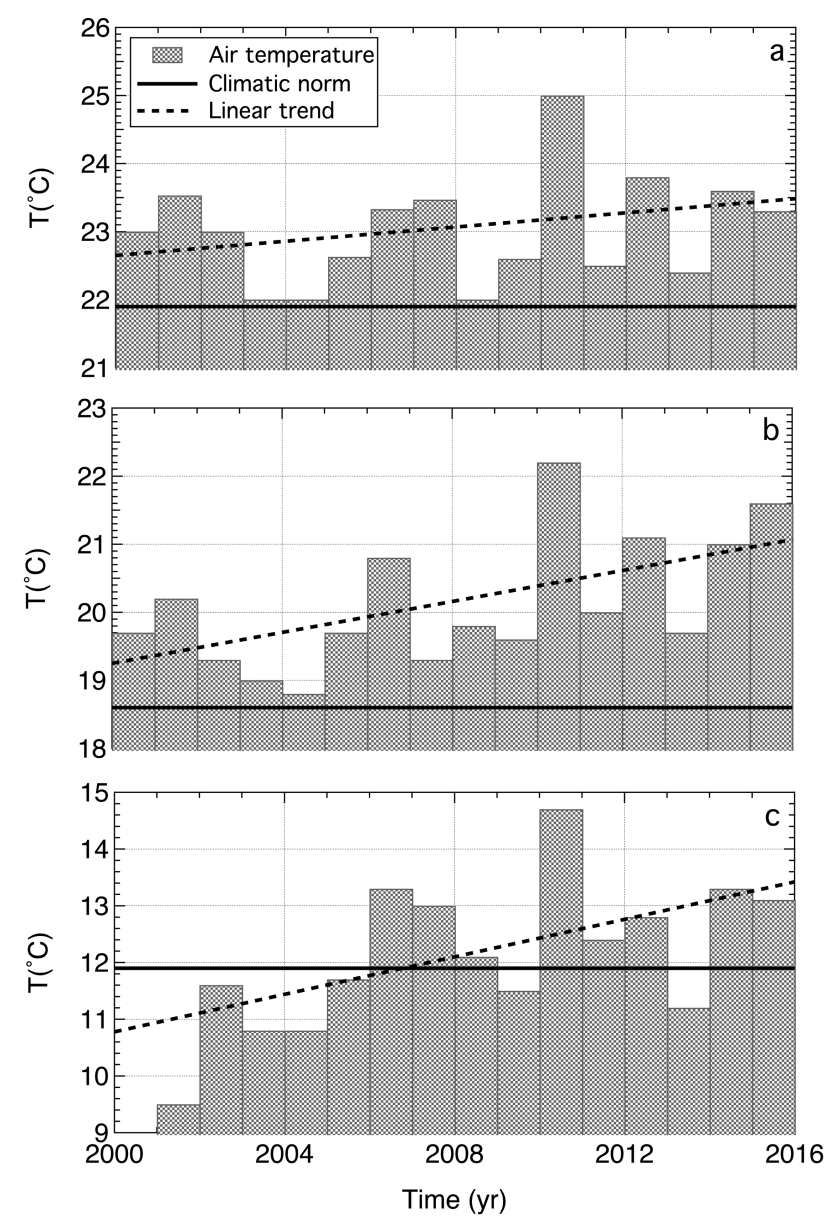

Fig. 3. Summer (JJA) average air temperatures, their climatic norms and linear trends for weather stations Sochi (a), Krasnaya Polyana (b) and Dzhuga (c).

The analysis reveals an intermitence of prevailing of either «warm» or «cold» precipitation amounts in all elevational zones. This intermittence happened synchronously in coastal and in piedmont zones. The variability in the middle altitude zone has a more complicated character. The common feature of all three zones is an increase of precipitation with positive temperatures (also marked by Kislov et al. (2011)) and an approach of both «warm» and «cold» precipitation to the climatic norm (Fig. 5).

\section{Concluding remarks}

National parks play an important role for studying the human impact on nature. They can be considered as a kind of reference territories with a minimum of anthropogenic intervention. Therefore, they provide opportunities not only to study natural processes, but also to evaluate consequences of human activities on adjacent territories. Taking into account the imminence of global warming consequences, growing men-
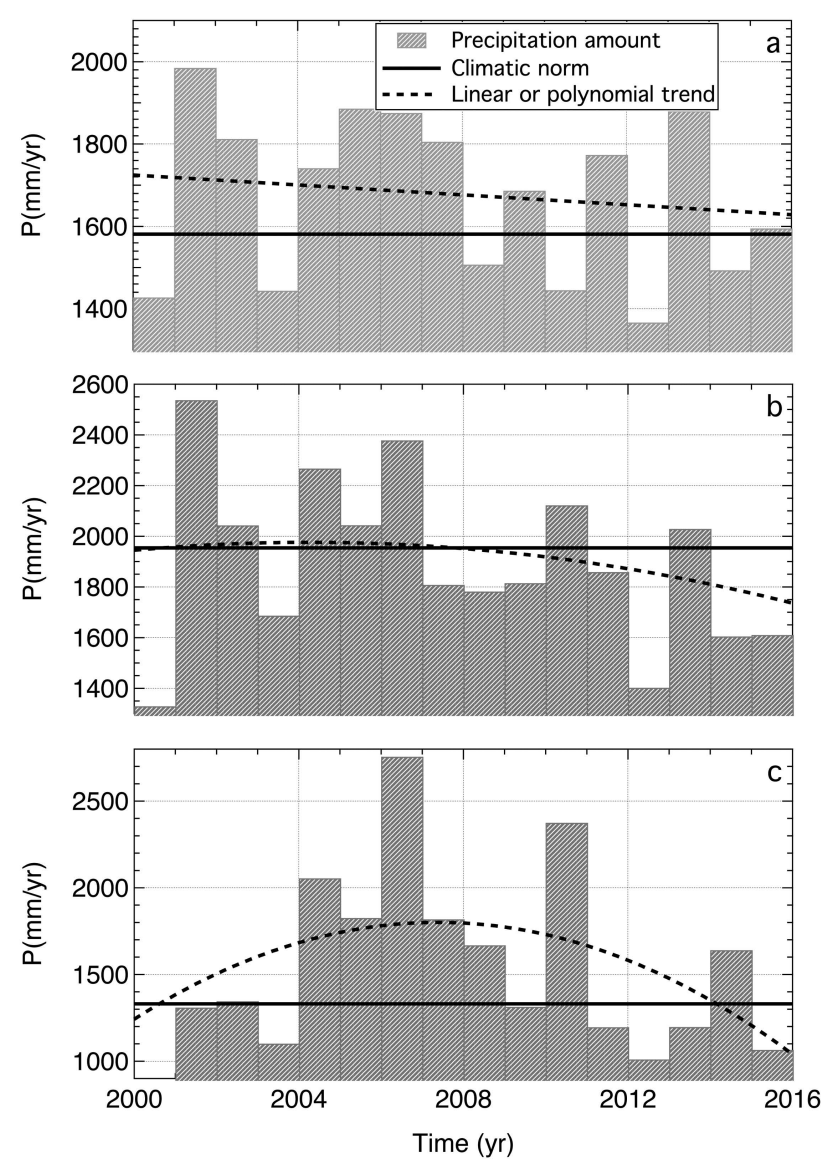

Fig. 4. Annual precipitation amount, their climatic norms and their trends for weather stations Sochi (a), Krasnaya Polyana (b) and Dzhuga (c).

aces of natural and man-caused catastrophes, decreasing areas of virgin natural landscapes, the value of PAs will be inevitably increasing. In our view PAs can be regarded as a kind of reference territories where the anthropogenic impact on nature is little compared to e.g. urban regions. That is why we find it quite reasonable and practical to monitor the current changes in climate conditions in the SNP, which occupies the greater part of the Greater Sochi municipal territory.

In the current study, we established that:

- Warming tendencies were present both in annual and seasonal air temperature time series

- A maximum warming manifested in the piedmont elevational zone

- Variations in mean annual and seasonal air temperatures in all elevational zones appeared synchronously, obviously because they were in general governed by the same synoptic events 

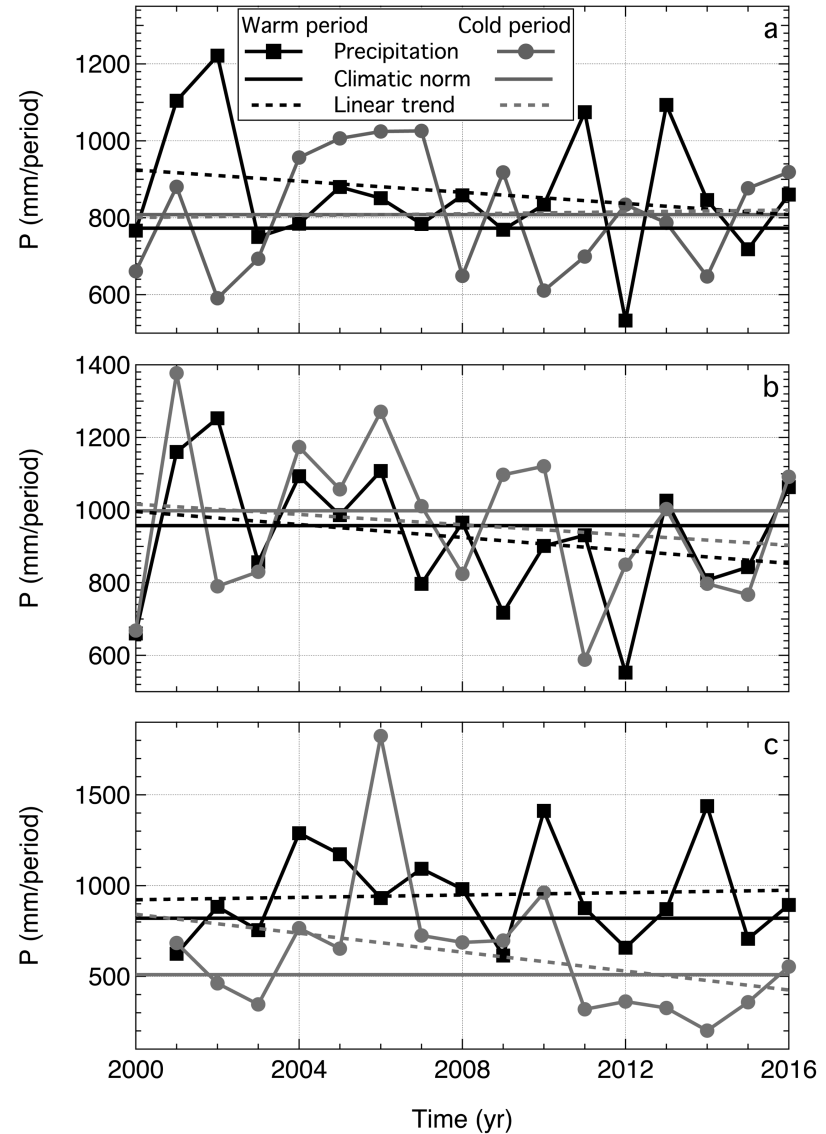

Fig. 5. Precipitation amount in cold period (ONDJFM) and in warm period (AMJJAS), their climatic norms and linear trends for weather stations Sochi (a), Krasnaya Polyana (b) and Dzhuga (c).

- In the coastal and piedmont zones, the amount of precipitation measured in the «cold» and in «warm» periods of the year were almost equal with the intermittent predominance of either of them

- In the middle altitude zone, the sum of the «warm» period precipitation prevailed over the sum of the «cold» period precipitation

- The highest interannual variability was established in the middle altitude zone

- Generally negative trends were marked in precipitation time series, both annual and seasonal.

\section{Acknowledgements}

Authors are grateful to Irina Fesenko and Alexander Zhivotov for preliminary discussions and suggestions. Their recommendations were very useful for improving the manuscript. The authors appreciate the numerous comments from an anonymous reviewer. His notes and suggestions enabled to considerably improve the manuscript.

\section{References}

Ashabokov B.A., Tashilova A.A., Kesheva L.A., Teunova N.B., Taubekova Z.A. 2017. Climatic changes of mean and extreme values of surface air temperature in the south of European Russia. Fundamental and Applied Climatology 1: 5-19. [In Russian]

Gruza G.V., Rankova E.Ya. 2012. Observed and expected climate changes of Russian Federation. Obninsk: RIHMI-WDS. 194 p. [In Russian]

Evstigneev V.P., Naumova V.A., Evstigneev M.P., Lemeshko N.A. 2016. Physiographic factors of seasonal distribution of linear trends in air temperature on the Azov-Black Sea coast. Russian Meteorology and Hydrology 1: 19-27.

IPCC. 2007. Climate Change 2007: Synthesis Report. Contribution of Working Groups I, II and III to the Fourth Assessment Report of the Intergovernmental Panel on Climate Change / Core Writing Team, R.K. Pachauri, A. Reisinger (Eds.). Geneva, Switzerland: IPCC. 104 p.

Kislov A.V. Grebenets V.I., Evstigneev V.M. Konischev V.N., Sidorova M.V., Surkova G.V., Tumel N.V. 2011. Complex evaluation of climate warming in the North of Eurasia. Moscow University Geography Bulletin. Series 5. Geography 3: 3-8. [In Russian]

Khovanova N.V. 2009. Temperature anomalies on the territory of Southern Federal District (1998-2007). University news. North-Caucasian region. Natural sciences series 2: 69-71. [In Russian]

Kondratyev K.Ya, Demirchyan K.S. 2001. Climate of the Earth and Kyoto protocol. Herald of the Russian Academy of sciences 71(311): 1002-1009. [In Russian]

Korchagina E.A. 2017. A study of air surface temperature and seasonal precipitation sums dynamics in Elbrus area (mid XXth - beginning of XXI century) In: Materials of the conference Sustainable development: problems, concepts, models (16-19.05.2017). Nalchik. P. 162-167. [In Russian]

Mokhov I.I., Semenov V.A. 2016. Weather and Climate Anomalies in Russian Regions Related to Global Climate Change. Russian Meteorology and Hydrology 2: 84-92.

Rybak E.A. 2006. Climatic features of Sochi National Park, In: B.S. Tuniev (Ed.): Invetarisation of main taxoconomical groups and cenoses, sozologigal investigations of the Sochi National Park. First results of the first Russian national park. Moscow: Prestige. P. 8-18. [In Russian]

Rybak E.A., Rybak O.O., Zasedatelev Y.V. 1994. Complex geographical analysis of the Greater Sochi region on the Black Sea Coast. GeoJournal 34(4): 507-513.

Rybak E.A., Rybak O.O. 2009. Intermittency in the regime of variability of the North Atlantic Oscillation University news. North-Caucasian region. Natural sciences series 6: 117-122. [In Russian]

Rybak O.O., Rybak E.A. 2013. Changes in the regime of air temperature and precipitation rate in the Black Sea region in the $20^{\text {th }}$ century. Polythematic online scientific journal of Kuban State Agrarian University 90(06): http://ej.kubagro.ru/2013/06/pdf/15.pdf. [In Russian]

Rybak O.O., Rybak E.A. 2015. Climate change in the South of Russia: tendencies and possibilities for prediction. Polythematic online scientific journal of Kuban 
State Agrarian University 111(07): http://ej.kubagro. $\mathrm{ru} / 2015 / 07 / \mathrm{pdf} / 30 . p d f$. [In Russian]

Second assessment report on climate change and its implications in the territory of the Russian Federation. Moscow: Roshydromet, 2014. 1008 p. [In Russian]

Volodin E.M. 2011. On the nature of some super-extreme anomalies of summer temperature. In: Analysis of anomalous weather conditions on the territory of Russia in summer of 2010. Moscow: Triada ltd. P. 48-57. [In Russian]

WMO. 2011. Comission for Climatology. Management Group Meeting. Denver, USA (26-29 October 2011). Denver: WMO. Available from: http://www.wmo.int/ pages/prog/wcp/ccl/mg/documents/mg2011/CCl-MG2011-Doc_10_climatenormals1.pdf.

\title{
РЕГИОНАЛЬНЫЕ ПРОЯВЛЕНИЯ ГЛОБАЛЬНЫХ КЛИМАТИЧЕСКИХ ИЗМЕНЕНИЙ (НА ПРИМЕРЕ ТЕРРИТОРИИ СОЧИНСКОГО НАЦИОНАЛЬНОГО ПАРКА, РОССИЯ)
}

\author{
Е. А. Рыбак ${ }^{1,2}$, О. О. Рыбак ${ }^{1}$ \\ ${ }^{1}$ Сочинский научно-исследовательский иентр РАН, Россия \\ ${ }^{2}$ Сочинский национальный парк, Россия
}

Сочинский национальный парк (СНП) занимает значительную часть территории Большого Сочи. Он расположен в нескольких высотных зонах, поэтому климатические условия здесь достаточно разнообразны. Средние климатические условия СНП достаточно хорошо изучены, однако глобальные и региональные изменения климата одновременно с долговременными тенденциями в естественной климатической изменчивости требуют регулярного обновления соответствующих вариаций на территории СНП. Это важно, в первую очередь, для отслеживания изменений и объяснения причин изменений биоразнообразия в СНП. В статье рассматриваются изменения основных метеорологических характеристик (температура воздуха, атмосферные осадки) в различных высотных поясах Сочинского национального парка. Анализируются среднегодовые и среднесезонные данные для репрезентативных станций за период с 2000 по 2016 гг. Показано, что помимо общих для всех высотных поясов тенденций в распределении температуры и осадков, важную роль играют локальные особенности и физикогеографическое положение пунктов наблюдения.

Ключевые слова: атмосферные осадки, изменение климата, особо охраняемые природные территории, Сочинский национальный парк, температура воздуха 